\title{
Electrochemical Quartz Crystal Microbalance and Rotating Ring Disk Electrode Analysis of Manganese Dioxide Electrodeposition for Thin Film Electrochemical Capacitors
}

\author{
A. D. Cross," I. Olcomendy, M. Drozd, ' A. F. Hollenkamp, and S. W. Donne ${ }^{a, z}$ \\ "Discinline of Chemistry, University of Newe astle. Callakhun NSW 2308, Auvtrulia \\ "Univernite de Fuitien, 86022 Pritien Cedex. Frunce \\ 'Ecole Atylechnique de 1 Universite de Nantes, Nantes Cedes 344300 , France \\ "CSIRO Division of Energy Tethnolegy, Clavem Sumh VIC 3169, Australia
}

\begin{abstract}
This work compares the electrxdeposition bethavior of thin litms of manganse dioxide produced frum solutions of four commonly availahle Mn(II) salts; namely, sulfate, chlorick, nilrale and acelale, as well as their comesponding acids. The deposition behavior is investigated in lerms of the masses of the thin films producel, calculated by integration of charge currenl during deposilion, and by the clectrochemical quarte crystal micnhalano: (LCC.M). (iencrally, it was shown that LOXM nusses deviated from the ntass cxpected from current integration, wilh increases ranging from 14-40\%, depending on the anion. The rnost notable deviations from this trend were the high-acid $(0.1 \mathrm{M})$ and low-Mn(II) $(0,01-0.001 \mathrm{M}$ ) solutions where $\mathrm{MnCl}$ and HCl were uscel. Ihis difference

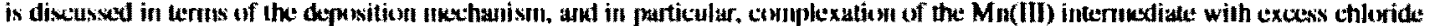

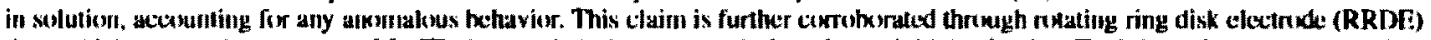
data, which was used w detect any $\mathrm{Mn}$ (III) that would be lowt lo the solution after an initial ox idaton. Their behavio as supentapaciur electrode materials has also heen compared.
\end{abstract}

2012 The Flectrochemical Society. [DOI: $10.1149 / 2.667302$ jes] All righls reserved.

Manuscript submitted August 28, 2012; revised manuscript received November 26, 2012. Published Decenter 20, 2012.

Energy storage.- With the world population increasing, and expected to continue to grow to $10-11$ billion by $2050,{ }^{\prime}$ so too do we expect to see an increase in global power demand. This demand is expected to reach 28 TW annually by the same year.' As such, the need for renewable energy sources such as solar, wind and geothermal will increase, given the finite nature of currently used fossil fuels. This in turn will require energy storage systems during periods of inereased production to compensate for periods when, say, overcast weather or night-time renders solar pancls incfective, or when wind is unavailable to power turbines. Energy storage systems are also essential for consumer electronic devices, and are also an cmerging technology in transportation. Even in this domain, power demands are increasing. placing greater stress on existing power sources. Given these factors, the development of energy storage devices that are capable of storing considerable amounts of energy. delivering that energy in an appropriate timeframe, and with the ability to sustain many charge and discharge cycles will be essential to maintain the anticiputed energy demands facing the world.

Manganese dioxide in energy storage systems. - Manganese dioxide has an extensive history in various energy storage systems, and in particular as the cathode material in alkaline and $\mathrm{I}$ eclanche hatteries. The basic structural building block of manganese dioxide is the $\left[\mathrm{Mn}\left(\mathrm{O}^{2}, \mathrm{OH}, \mathrm{H}_{2} \mathrm{O}\right)_{6}\right]^{2 t}$ octahedral unit (abbreviated as $\left[\mathrm{MnO}_{6}\right]$ ), the arrangement of which is capable of forming many differing structures, with over 30 synthetic and natural structures currently classified. ${ }^{1-7}$ Edge and/or comer sharing between these $\left[\mathrm{MnO}_{6}\right]$ octahedra allows for the formation of materials with one-, two- or threedimensional tunnels. The most common phases contain tunnel structures with dimensions $[\mathrm{n} \times \mathrm{m}]$, where $n$ and $m$ represent the number of oxtahedral subunits in the a-b plane. Typical structural varieties include the stoichiometric pyrolusile ( $\beta-\mathrm{MnO}_{2}, \mid 1 \times \|$ tunnels) and ramsdellite $\left(|| \times 2 \mid\right.$ tunnels) structures, $\gamma-\mathrm{MnO}_{2}$, which is best defined as a random intergrowth of the $[1 \times 1]$ and $[1 \times 2]$ tunnel structures, with larger tunnels, such as $\alpha-\mathrm{MnO}_{2}([2 \times 2]), \lambda-\mathrm{MnO}_{2}$, which has a spinel struclure, and in the extreme casc, hirnessite $\left(\mathrm{h}-\mathrm{MnO}_{2} ;(2 \times \infty)\right)$ which is composed of flat sheet-like layers of edge sharing $\left[\mathrm{MnO}_{6}\right]$ octahedra.

Manganese dioxide can be produced from a variety of synthetic methods, including thermal, chemical or electrochemical means. Specific approaches include reduction of $\mathrm{Mn}^{4+16+n+4,4}$ oxidation of

E-mail: scoltdonne fo nowcastle.edu au
$\mathrm{Mn}^{2+}{ }^{6-8}$ as well as disproportionation of $\mathrm{Mn}$ (III) species. Despite this variely, anodic electrodeposition of manganese dioxide from an acidic $\mathrm{Mn}^{2+}$ solution is the most commonly used method for commercial applicutions.

The use of $\mathrm{MnO}_{2}$ as a supercapacilor electrode tnaterial was lirst reported by Lee und Goodenough in 1999, describing the pseudocapacitive behavior of amorphous $\mathrm{MnO}_{2}$, and giving a specific capacitance of $200 \mathrm{~F} / \mathrm{g}$. While not performing as well as the then prototypical metal oxide capacitor naterial, amorphous hydrated ruthenium dioxide $\left(\mathrm{a}-\mathrm{RuO}_{2}, \mathrm{xH}_{2} \mathrm{O}\right.$ with a specific capacitance $\left.>700 \mathrm{~F} / \mathrm{g}{ }^{10}\right)$ it was advantageous in many areas, particularly when taking into account the cost of ruthenium-based materials, due to its scarcity when compared to more abundant metals such as manganese. The work by Lee and Goodenough, and indeed the vast majority of work in the area of $\mathrm{MnO}_{2}$ capacitors, typically involves producing an electrode film via affixing high-surface area $\mathrm{MnO}_{2}$ powders to the substrate using a polymer binder. This typically yields an electrode with a specific capacitance of $125-250 \mathrm{~F} / \mathrm{g}$, 911 though some work describing the use of electrodeposition was also published in subsequent years, giving specific capacitances of approximatcly $400 \mathrm{~F} / \mathrm{g} .{ }^{12}$ Flectrodeposition offers advantages in the formation and processing of electrode films, and also removes the requirement for binding additives in the electrode film.

The focus of work by the authors in recent years has been on the use of electrodeposition as a means of producing thin films of manganese dioxide for supercapacitor applications. These studies have included (i) the effect of $\mathrm{H}_{2} \mathrm{SO}_{4}$ and $\mathrm{Mn}^{2+}$ concentration in the depositing solution, as well as how the deposition potential and deposition lime affect the resulting specific capacitance. ${ }^{17}$ (ii) the effect of constant cument versus constant potential during deposition. ${ }^{14}$ and (iii) evaluating a number of methods for accurately estimating the mass of a thin film of manganese dioxide produced by electrodeposition. ${ }^{\text {I }}$ Here, it was found that a combination of high acid concentration. low manganese concentration, and lower (i.e. mass transport-limited) deposition potentials were the most advantageous, mutinely giving specific capacitances $>2000 \mathrm{~F} / \mathrm{g}$.

Manganese dioxide electmdeposition merhanism. - The current understanding of the manganese dioxide electrodeposition mechanism hy oxidation of acidic $\mathrm{Mn}^{21}$ solutions has found that two main pathways are possible, dependent on the acid concentration of the solution from which deposition occurs. ${ }^{16}$ zil As kuch, these two pathways have been termed the high-acid and low-acid paths. Both of these paths are summarized in Figure 1. 


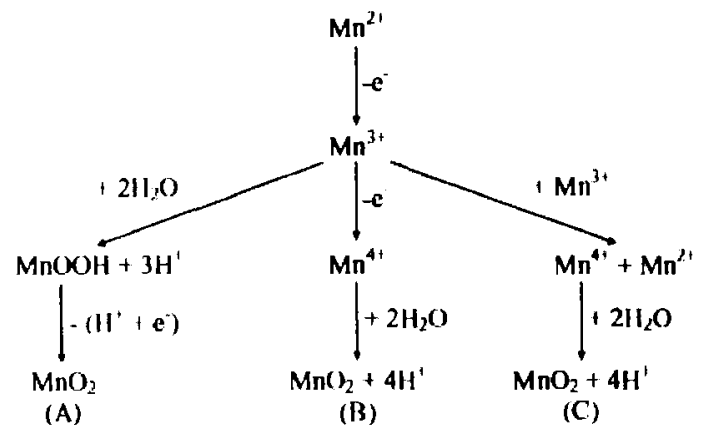

Figure 1. Summary of manganese dioxide electrodeposition mechanism pathways, showing the low-acid (A) and high-acid (C) cases, as well as the direct Iwo-electron oxidation (B).

Irrespective of the path, the first step in the process is the singleelectron oxidation of $\mathrm{Mn}^{2+}$ to soluble $\mathrm{Mn}^{3+}$. In the low-acid path (A) this is then followed by hydrolysis of $\mathrm{Mn}^{3+}$ to form solid $\mathrm{MnOOH}$ on the electrode surface. The final step is the solid-state oxidation of $\mathrm{MnOOH}$ to $\mathrm{MnO}_{2}$. The high-acid path (C) diflers somewhat in that after the initial oxidation two $\mathbf{M n}^{3+}$ ions disproportionate to form $\mathrm{Mn}^{2+}$ and $\mathrm{Mn}^{4+}$, the latter of which is then hydrolysed to form solid $\mathrm{MnO}_{2}$ on the electrode surface. The direct pathway (B), while theoretically possible, has not been reported in the literature as of the writing of this paper.

This work - The work presented here aims to build upon information obtained from previous studies made by the authors. Here, using the electrochemical quartz crystal microbalance (EQCM) and rotating ring-disk clectrode (RRDF), we will characterize the electrodeposition of manganese dioxide from solutions of various $\mathrm{Mn}$ (II) salts and their corresponding acids. The aim is to explain any differences in the deposition mass and resulting performance as a supercapacitor electrode of the films produced from these various anionic solutions in terms of the anion properties and any interactions with the $\mathrm{Mn}^{2+n+14+}$ ions in solution.

\section{Experimental}

Materials. Manganese dioxide deposits were prepared from solutions of a Mn(II) salt and the corresponding acid. The manganese salts were sourced from $\mathrm{MnSO}_{4} \cdot \mathrm{H}_{2} \mathrm{O}$ (Sigma-Aldrich; $\geq 99 \%$ ),
$\mathrm{MnCl}_{2} .4 \mathrm{H}_{2} \mathrm{O}$ (Sigma-Aldrich; 96.0-101\%), $\mathrm{Mn}\left(\mathrm{NO}_{3}\right)_{2}$ (SigmaAldrich; >97\%) and $\mathrm{Mn}\left(\mathrm{CH}_{3} \mathrm{COO}\right)_{2} .4 \mathrm{H}_{2} \mathrm{O}$ ( $\geq 99 \%$; Acros Organies). The corresponding acids used in these experiments were $\mathrm{H}_{2} \mathrm{SO}_{4}$ (Ajax Finechem; 98\%), $\mathrm{HCl}$ (Ajax Finechem; 32\%), $\mathrm{HNO}_{3}$ (BDH Chemicals; 69-71\%) and $\mathrm{CH}_{3} \mathrm{COOH}$ (Sigma-Aldrich; $\geq 99.99 \%$ ). The electrolyte used for performance evaluation as a supercapacitor electrode was a solution of $0.5 \mathrm{M} \mathrm{Na}_{2} \mathrm{SO}_{4}$ (Sigma-Aldrich; $\geq 99 \%$ ). All solutions were made using ultra-pure Milli-Q water (resistivity $>18.2 \mathrm{M} \Omega . \mathrm{cm}$ ). Electrodeposition of manganese dioxide was carried out using a matrix of solutions containing $0.001-0.1 \mathrm{M}$ acid solution together with 0.001-0.1 $\mathrm{M}$ of the $\mathrm{Mn}$ (II) salt. In total the matrix consisted of nine different solutions for each individual anion.

Elec:Inedeposition method.... The electrudeposition cell consisted of a $250 \mathrm{~mL}$ beaker, which contained the platinum working electrode in the electrochemical quartz crystal microbalance (EQCM; Stanford Research Systems QCM200) crystal housing (working electrode area $=1.325 \mathrm{~cm}^{2}$ ), a graphite rod serving as the counter electrode (area $6.3 \mathrm{~cm}^{2}$ ), and a saturated calomel reference electrode (SCE), against which all potentials were measured and reported.

The appropriate deposition potential for this work was determined by first performing a linear sweep voltammetry experiment, by measuring the current when the potential was swept from the open-circuit potential to $1.6 \mathrm{~V}$ versus SCE at a rate of $5 \mathrm{mV} / \mathrm{s}$ (Perkin-Elmer VMP II controlled by EC-Lab software (BioLogic, V6.80)). From these experiments, both non-diffusion and diflusion-limited potentials were selected for chronoamperometric electrodeposition from each solution. Table I summarizes the deposition conditions, including the deposition potentials used.

For electmdeposition, the working, counter and reference electrodes were placed in the cell and attached to the potentiostat, as in the linear sweep experiments. The software was configured so as to step the potential of the working electrode surface to the deposition potential determined from linear sweep voltammetry. The potential was held at this value for $30 \mathrm{~s}$, after which the electrodes were washed thoroughly with Milli-Q water and transferred to a solution of $0.5 \mathrm{M} \mathrm{Na}_{2} \mathrm{SO}_{4}$ for cyclic voltammetry, the conditions of which will be outlined later.

The mass of manganese dioxide produced by electrodeposition was calculated from numerical integration (using the trapezoidal rule) of the current with respect to time during the chronoamperometry experiments. It is then assumed that all of the charge passed during chronoamperometry was involved in the two-electron oxidation of

Table I. Summary of the data collected In thls work for the (a) sulfate, (b) chloride, (c) nitrate and (d) acetate electrolytes.

(a) Sulfalc duta

\begin{tabular}{|c|c|c|c|c|c|c|c|}
\hline \multirow{2}{*}{$\begin{array}{l}{\left[\mathrm{H}_{2} \mathrm{SO}_{4}\right]} \\
\text { (M) }\end{array}$} & \multirow{2}{*}{$\begin{array}{c}{\left[\mathrm{MnSO}_{4}\right]} \\
(\mathrm{M})\end{array}$} & \multirow{2}{*}{$\begin{array}{c}\text { Depoxition Potential } \\
\text { (V vs SCL) }\end{array}$} & \multirow{2}{*}{$\begin{array}{l}\text { Integrated Mass } \\
\left(\mu \mathrm{g} / \mathrm{cm}^{2}\right)\end{array}$} & \multirow{2}{*}{$\begin{array}{c}\text { EOCM Mass } \\
\left(\mu \mathrm{g} / \mathrm{cm}^{2}\right)\end{array}$} & \multirow{2}{*}{$\begin{array}{l}\text { \% Mn(III) Lost } \\
\text { (RRDLi) }\end{array}$} & \multicolumn{2}{|c|}{ Specific Capacitance $\left(F / g / \mathrm{cm}^{2}\right)$} \\
\hline & & & & & & Intceralcul Muss & LQCM Muss \\
\hline \multirow{6}{*}{0.1} & 0.1 & 1.200 & 15.1 & 20.5 & 10.1 & 294 & 216 \\
\hline & & 1.500 & 8.3 & 7.5 & & 363 & 402 \\
\hline & 0.01 & 0.900 & 0.5 & 1.9 & 2.7 & 2503 & 66.3 \\
\hline & & 1.100 & 0.6 & 2.2 & & 2140 & 617 \\
\hline & 0.001 & 0.900 & 0.5 & 0.4 & 6.4 & 4082 & 5.381 \\
\hline & & 1.100 & 0.8 & 0.3 & & 2944 & 6750 \\
\hline \multirow{6}{*}{0.01} & 0.1 & 1.000 & 2.3 & 4.1 & 0.5 & 600 & 340 \\
\hline & & 1.200 & 4.2 & 6.1 & & 532 & 364 \\
\hline & 0.01 & 1.100 & 2.5 & 4.2 & 0.6 & 1385 & 826 \\
\hline & & 1.400 & 2.3 & 2.5 & & 434 & 383 \\
\hline & 0,001 & 0.900 & 0.5 & 1.9 & 0.8 & 1703 & 451 \\
\hline & & 1.100 & 0.8 & 1.7 & & 1094 & 500 \\
\hline \multirow{6}{*}{0.001} & 0.1 & 0.900 & 2.0 & 4.8 & 0.1 & 813 & 337 \\
\hline & & 1.100 & 6.3 & 10.8 & & 645 & 377 \\
\hline & 0.01 & 1.0000 & 2.7 & 5.1 & 0.3 & 388 & 205 \\
\hline & & 1.200 & 5.5 & 9.9 & & 575 & 322 \\
\hline & 0,001 & 1.100 & 1.1 & 2.4 & $<0.1$ & 646 & 292 \\
\hline & & 1.200 & 1.3 & 1.4 & & 5.30 & 497 \\
\hline
\end{tabular}




\begin{tabular}{|c|c|c|c|c|c|c|c|}
\hline \multirow{2}{*}{$\begin{array}{l}\|\mathrm{HC}\| \\
(\mathrm{M})\end{array}$} & \multirow{2}{*}{$\underset{(\mathrm{M})}{\left|\mathrm{MnCl}_{2}\right|}$} & \multirow{2}{*}{$\begin{array}{l}\text { Deposition Prutential } \\
\text { (V vs SCE) }\end{array}$} & \multirow{2}{*}{$\begin{array}{l}\text { Intugruted Mass } \\
\left(\mu \mathrm{g} / \mathrm{cm}^{2}\right)\end{array}$} & \multirow{2}{*}{$\begin{array}{l}\text { LQCM Mass } \\
\left(\mu \mathrm{g} / \mathrm{cm}^{2}\right)\end{array}$} & \multirow{2}{*}{$\begin{array}{l}\text { * Mn(III) Lost } \\
\text { (RRDE) }\end{array}$} & \multicolumn{2}{|c|}{ 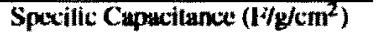 } \\
\hline & & & & & & Integrated Mass & $\overline{\text { EQCM Mass }}$ \\
\hline \multirow{6}{*}{0.1} & 0.1 & 1.150 & 37.4 & 48.2 & 47.8 & 382 & 297 \\
\hline & & 1.250 & 52.1 & 52.4 & & 257 & 256 \\
\hline & 0.01 & 1.250 & 30.7 & $\mathbf{3 . 1}$ & 29.3 & 139 & 1381 \\
\hline & & 1.450 & 20.6 & 3.2 & & 261 & 1684 \\
\hline & 0.001 & 1.250 & 28.4 & 0.7 & 92.0 & 35 & 1340 \\
\hline & & $1.4(0)$ & 20.8 & 0.4 & & 254 & 14026 \\
\hline \multirow{5}{*}{0.01} & 0.1 & $\begin{array}{l}1.100 \\
1.350\end{array}$ & $\begin{array}{l}40.5 \\
66.5\end{array}$ & $\begin{array}{l}44.9 \\
82.4\end{array}$ & 5.0 & $\begin{array}{l}316 \\
352\end{array}$ & $\begin{array}{l}285 \\
284\end{array}$ \\
\hline & 0,01 & 1.050 & 4.0 & 14.8 & 0.2 & 625 & 169 \\
\hline & & 1.130 & 10.1 & 17.5 & & 535 & 309 \\
\hline & 0.001 & 1.060 & 1.3 & 2.6 & 0.5 & 724 & 352 \\
\hline & & 1.120 & 1.8 & 1.7 & & 736 & 777 \\
\hline \multirow{6}{*}{0.001} & 0.1 & 1.100 & 41.6 & 45.5 & 0.5 & 311 & 284 \\
\hline & & 1.350 & 66.4 & 77.3 & & 289 & 248 \\
\hline & 0.01 & 1.100 & 7.4 & 13.1 & 0.2 & 509 & 287 \\
\hline & & 1.320 & 13.8 & 18.2 & & 353 & 268 \\
\hline & 0.001 & 0.900 & 1.1 & 0.6 & 1.2 & 988 & 1906 \\
\hline & & 1.100 & 2.0 & 4.3 & & 483 & 229 \\
\hline \multicolumn{8}{|l|}{ (c) Nilralc datu } \\
\hline \multirow{2}{*}{$\begin{array}{l}{\left[\mathrm{HNO}_{3}\right]} \\
(\mathrm{M})\end{array}$} & \multirow{2}{*}{$\begin{array}{l}{\left[\mathrm{Mn}\left(\mathrm{NO}_{3} h\right]\right.} \\
(\mathrm{M})\end{array}$} & \multirow{2}{*}{$\begin{array}{l}\text { Deposition Potential } \\
\text { (V ys SCi) }\end{array}$} & \multirow{2}{*}{$\begin{array}{c}\text { Integrated Mass } \\
\left(\mu \mathrm{g} / \mathrm{cm}^{2}\right)\end{array}$} & FQCM Mass & Mn(III) Lost & Specific Capacita & $\left(\mathrm{F} / \mathrm{g} / \mathrm{cm}^{2}\right)$ \\
\hline & & & & $\left(\mu \mathrm{y} / \mathrm{cm}^{2}\right)$ & (KKDLE) & Integrated Mass & EQCM Muss \\
\hline & 0.1 & 1.125 & 6.9 & 1.3.1 & 0.3 & 302 & 159 \\
\hline & & 1.275 & 20.7 & 31.3 & & 275 & 182 \\
\hline 0.1 & 0.01 & 1.200 & 5.4 & 13.1 & 2.1 & 245 & 101 \\
\hline & & 1.300 & 4.5 & 5.6 & & 257 & 206 \\
\hline & 0.001 & 0.925 & 0.3 & 0.4 & 7.3 & 3291 & 2468 \\
\hline & & 1.125 & 0.6 & 0.3 & & 1891 & 3782 \\
\hline & 0.1 & 1.050 & 12.6 & 14.8 & $=0.1$ & 315 & 269 \\
\hline & & 1.250 & 37.0 & 35.9 & & 167 & 173 \\
\hline 0.01 & 0.01 & 1.100 & 2.5 & 7.6 & 0.1 & 383 & 126 \\
\hline & & 1.200 & 3.4 & 6.3 & & 296 & 160 \\
\hline & 0.001 & 1.060 & 1.2 & 5.1 & 0.9 & 952 & 225 \\
\hline & & 1.120 & 1.1 & 3.9 & & 1040 & 287 \\
\hline & 0.1 & 0.850 & 1.8 & 7.6 & $<0.1$ & 551 & $|3|$ \\
\hline & & 1.100 & 18.8 & 28.0 & & 364 & 244 \\
\hline 0.001 & 0.01 & 1,050 & 2.9 & 8.3 & 0,4 & 424 & 148 \\
\hline & & 1.250 & 6.7 & 13.3 & & 344 & 174 \\
\hline & 0.001 & 0.9 .50 & 0.8 & 3.7 & 0.4 & 1400 & 303 \\
\hline & & 1.125 & 1.4 & 5.8 & & 519 & 125 \\
\hline (d) Acetate dal & & & & & & & \\
\hline $\mathrm{CH}_{3} \mathrm{COOH}$ & $\left|\mathrm{Mn}\left(\mathrm{CH}_{3} \mathrm{CO}(\mathrm{O})\right)_{2}\right|$ & Dxensition Potcential & Intcerated Mass & LOCMM Mass & T: Mn(III) Los! & Specilic Capacita & $\mathrm{x}\left(1 / \mathrm{g} / \mathrm{cm}^{2}\right)$ \\
\hline (M) & (M) & (V v SCF) & $\left(\mu \mathrm{g} / \mathrm{cm}^{2}\right)$ & $\left(\mu \mathrm{g} / \mathrm{cm}^{2}\right)$ & (RRDE) & Integraled Mass & $\overline{\text { EQCM Mass }}$ \\
\hline & 0.1 & 0.850 & 5.8 & 10.2 & $<0.1$ & 901 & 640 \\
\hline & & 1.050 & 7.7 & 12.5 & & 578 & 445 \\
\hline 0.1 & 0.01 & 0.950 & 5.4 & 3,0 & $\approx 0.1$ & 3546 & 8000 \\
\hline & & 1.250 & 4.5 & 6.4 & & 304 & 268 \\
\hline & 0.001 & 1.000 & 0.8 & 0.2 & $<0.1$ & 1575 & 7875 \\
\hline & & 1.200 & 1.9 & 1.9 & & 533 & 666 \\
\hline & 0.1 & 0.650 & 11.8 & 10.5 & $<0.1$ & 764 & 859 \\
\hline & & 0.770 & 20.7 & 22.7 & & 959 & $10 \$ 2$ \\
\hline 0.01 & 0.01 & 0.950 & 8.2 & 13.7 & 2.0 & 398 & 298 \\
\hline & & 1.200 & 12.2 & 18.7 & & 36.3 & 296 \\
\hline & 0.001 & 0.950 & 0.9 & 2.6 & 6.6 & 1823 & 800 \\
\hline & & 1.150 & 1.1 & 3.5 & & 1857 & 728 \\
\hline & 0.1 & 0.900 & 27.5 & 39.9 & $<0.1$ & 295 & 254 \\
\hline & & 1.100 & 35.5 & 48.6 & & 301 & 275 \\
\hline 0.001 & 0.01 & 0.750 & 2.3 & 7.2 & 5.8 & 1236 & 490 \\
\hline & & 1.150 & 6.8 & 10.3 & & 665 & 551 \\
\hline & 0.001 & 0.800 & 0.8 & 5.1 & 4.7 & 890 & 175 \\
\hline & & 1,100 & 1.9 & 6.8 & & 661 & 231 \\
\hline
\end{tabular}


$\mathrm{Mn}^{21}$ in solution to $\mathrm{MnO}_{2}$, giving a number of moles and hence mass of $\mathrm{MnO}_{2}$ deposited. This is calculated by

$$
\mathbf{m}=\frac{\mathbf{Q M}}{\mathbf{n F}}
$$

where $Q$ is the charge passed (C), $\mathrm{M}$ is the molar mass of $\mathrm{MnO}_{2}$ $(86.9368 \mathrm{~g} / \mathrm{mol}), \mathrm{n}$ is the number of electrons involved in this process (n 2 ) and $F$ is the Faraday constant $(96486.7 \mathrm{C} / \mathrm{mol})$.

Electrochemical quartz crystal microbalance (EQCM).... EQCM offers the ability to track changes in electrode mass over time by detecting changes in the resonant frequency of a quartz piezolectric crystal on which the electrode is mounted, acconding to the Sauerbrey equation; ${ }^{21}$ i.c.,

$$
\Delta m=\frac{\Delta f}{C_{r}}
$$

where $\Delta m$ is the change in mass $\left(\mu \mathrm{g} \cdot \mathrm{cm}^{-2}\right), \Delta \mathrm{f}$ is the change in frequency $(\mathrm{Hz})$, and $\mathrm{C}_{1}$ is the sensitivity fuctor of the quartz crystal. The value of $C_{f}$ has been previously determined to be $56.6 \mathrm{~Hz} \mathrm{~cm}^{2} . \mu \mathrm{g}^{-1}$ hy the deposition of $\mathrm{Cu}$ metal from an acidified $\left(1 \mathrm{M} \mathrm{H}_{2} \mathrm{SO}_{4}\right)$ solution of $\mathrm{CuSO}_{4}(10 \mathrm{mM})$.

Cyclic voltammetry.- After electrodeposition of $\mathrm{MnO}_{2}$ onto the working electrode surface via chronoamperometry, the working, reference and counter electrodes were transferred to a cycling solution of $0.5 \mathrm{M} \mathrm{Na}_{2} \mathrm{SO}_{4}$. This cell was cycled between 0-0.8 V vs SCE at a rate of $5 \mathrm{mV} / \mathrm{s}$ for 50 cycles. While it is typical to conduct supercapacitor electrode cycling over more cycles, we have seen in previous work that cycling at a low rate for limited cycles is more demanding on pseudo-capacitive electrode materials. ${ }^{1322}$ Capacity was calculated from the charge passed during the discharge (cathodic) portion of the cycle, which was then used to determine the capacitance by dividing by the potential window during cycling (i.e., $0.8 \mathrm{~V}$ ). Specific capacitance (SC) was then calculated by dividing the capacitance by the mass of electroactive manganese dioxide calculated from either the electrodeposition current or EQCM analysis, i.e.,

$$
\mathbf{S C}=\frac{\mathrm{Q}}{\mathrm{VM}}
$$

where $Q$ is the cathodic capacity (C), $V$ is the potential window used during cyclic voltammetry (V), and $M$ is the mass ( $B$ ).

Rotuting ring-disk electrode (KRDE) voltammetry... Similarly to the FQCM analysis, the three electrodes (Pt working (Pine Instruments in the FA series quick change electrode holder; $5 \mathrm{~mm}$ diametcr), graphite counter and saturated calomel reference electrodes) were placed in a five-necked $250 \mathrm{ml}$, round bottom flask. All the electrodes were connected to the appmopriate channels of a Pine Instrument Company bipotentiostat (modcl AFCBP1), with the working electrode connected via an analytical rotator (Pine Instrument Company, model AFMSRXE). To perform the experiment, the platinum disk potential was set to sweep from the open circuit potential to $1.6 \mathrm{~V}$ versus $S C E$, while the ring potential was set at $0.6 \mathrm{~V}$ versus SCE. This ring potential, when combined with electrode rotution, which was set at $500 \mathrm{rpm}$, allowed for any soluble Mn(III) intermediale produced during deposition to be swept away from the disk surface to the ring where it was reduced hack to $\mathrm{Mn}$ (II) at its potential. The collection efficiency of this process $\left(N_{D}\right)$ was calculated by

$$
N_{D}=-\frac{i_{k}}{i_{D}} \times 100 \%
$$

where $i_{R}$ is the ring current and $i_{n}$ is the disk current. The collection efficiencies were compared to the well behaved $\mathrm{Fe}(\mathrm{CN})_{6}{ }^{3} / 4$ system, which has a measured collection efficiency of $23.43 \%$ for this electrode system, to determine a percentage of $\mathrm{Mn}$ (III) that remains in some soluble form during deposition (\% Mn(III) lost). That is, the measured collection efficiency for the manganese dioxide electrodeposition experiment ( $\mathrm{N}_{\mathrm{D}}\left(\mathrm{MnO}_{2}\right.$ Deposition) was compared to that of the

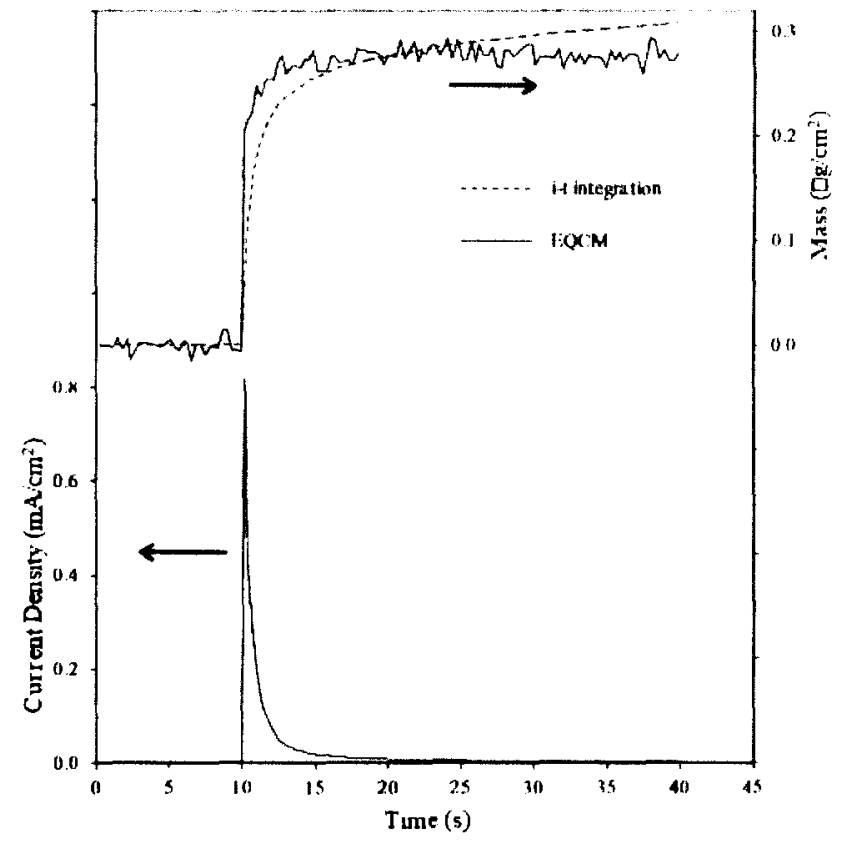

Flgure 2. Current and mass versus time for chronoampenometry of a solution containing $0.001 \mathrm{M} \mathrm{MnSO}_{4}+0.1 \mathrm{M} \mathrm{H}_{2} \mathrm{SO}_{4}$. Chronoamperometry step-polential was sct at $0.900 \mathrm{~V}$ vs SCE for $30 \mathrm{~s}$.

ideal, completely soluble $\mathrm{Fe}(\mathrm{CN})_{6}{ }^{3 / 4}$ system $\left(\mathrm{N}_{\mathrm{D}}\left(\mathrm{Fc}(\mathrm{CN})_{6}{ }^{3 / 4}\right)\right)$, expressed as a pereentage; i.e.,

$$
\text { \% Mn(ll1)Lost }=\frac{\mathrm{N}_{\mathrm{D}}\left(\mathrm{MnO}_{2} \text { Deposition }\right)}{\mathrm{N}_{\mathrm{D}}\left(\mathrm{Fe}(\mathrm{CN})_{6}^{3-/ 4-}\right)} \times 100 \%
$$

\section{Results and Discussion}

Electrodeposition. - Electrodeposition of mangancsc dioxide has in our previous studies been primarily achieved using solutions of $\mathrm{MnSO}_{4}$ and $\mathrm{H}_{2} \mathrm{SO}_{4}$, and as such, all results from this study on properties such as deposition potential, deposition mass and percentage of recovered $\mathrm{Mn}$ (III) will be compared to samples deposited from $\mathrm{MnSO}_{4}+\mathrm{H}_{2} \mathrm{SO}_{4}$ solutions. Typical chronoamperometry (i vs $\mathrm{l}$ ), and mass versus time data, from such a deposition are shown in Figure 2. As expected, the chronoumperometric data showed a pulse in current ut the onset of the applied potential, followed by a steady decrease in current duc to the consumption of $\mathrm{Mn}$ (II) species at the clectrode surface, with its subsequent replenishment duc to diffusion and migration.

EQCM data.- Flectrodeposition experinents were performed using all solutions, with the compiled data for all solutions shown in Figure 3. As can be seen, there is a strong linear trend between the masses determined by EQCM when compared to the mass calculated by current integration. It is generally seen that the EQCM masses are larger than the integrated current masses, with this increase varying between $14 \%$ in the case of chloride, $27 \%$ for sulfate, $34 \%$ for acetale, and $40 \%$ for nitrate union solutions (percentuge increases determined by linear sum of least squares analysis). This linear relationship was shown to hold for masses ranging from $<1 \mu \mathrm{g} / \mathrm{cm}^{2}$, through to the upper end where masses were calculated to be $\sim 66 \mu \mathrm{g} / \mathrm{cm}^{2}$ hy integration and $77.82 \mu \mathrm{g} / \mathrm{cm}^{2}$ hy F.OCM in the case of diffusion-limited electrodeposition from solutions of low concentrations of IICI and high concentrations of $\mathbf{M n C l}_{2}$.

The most notable exception was the chloride data series, specifically those solutions based on the $0.1 \mathrm{M} \mathrm{HCl}$ solution, where the current resulting from chronoamperometric deposition 


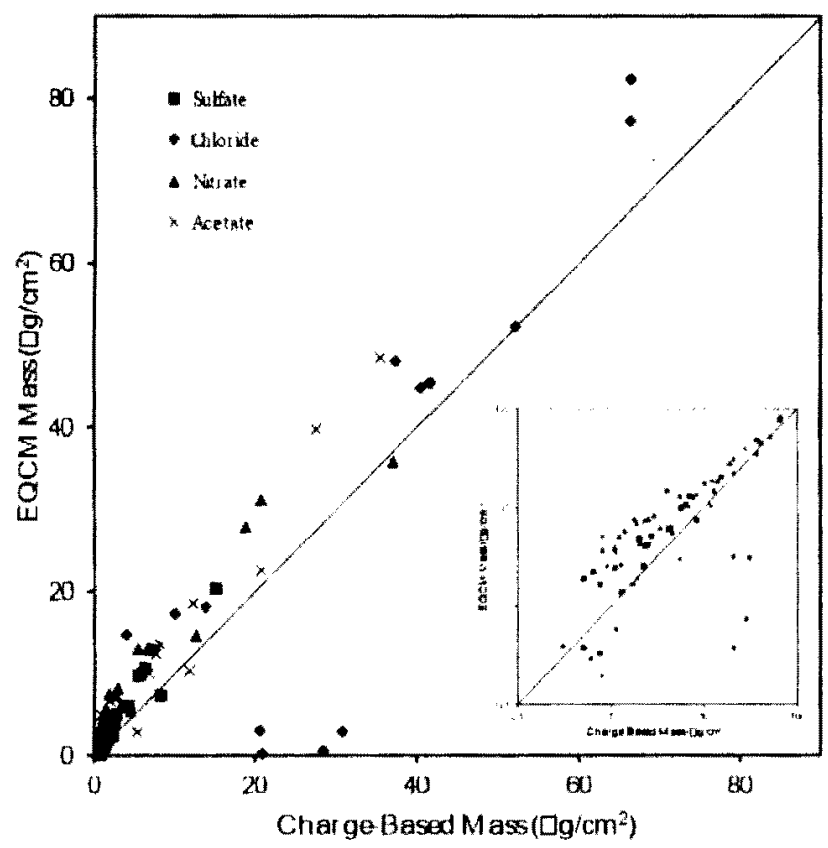

Figure 3. Combined EOCM data for all solutions used to electrodeposit manganese dioxide in this study. Electrodeposition solutions were based on sulfate, nitrate, chloride and acclate salts of $\mathrm{Mn}$ (II) (0.001-0). I M concentration), combined with the corresponding acid solution $(0.001-0.1 \mathrm{M})$. Electrokepesition was via chronoamperometry (30 s deposition) al a range of different potentials. The working clectrode was $19\left(1.325 \mathrm{~cm}^{2}\right)$, reference electrode was $\mathrm{SCL}$, and the counter electrock a graphite rod $\left(6.3 \mathrm{~cm}^{2}\right)$. The diugonal line indicates direct comrelation, while the inset tigure employs a logarithmic seale to provide mure detuil on the low mass samplex mepared.

suggested that masses of manganexe dioxide should equal 30.7 and $28.4 \mu \mathrm{g} / \mathrm{cm}^{2}$ for mass transport-limited conditions $(0.01 \mathrm{M}$ and $0.001 \mathrm{M} \mathrm{MnCl}_{2}$, respectively). If EQCM masses were to follow the Irend of an increase of $14 \%$ over integral masses, as shown by other chloride electrodeposition data, we should expect masses of 34.9 and $32.3 \mu \mathrm{g} / \mathrm{cm}^{2}$, respectively, when in fact a comparison instead shows that masses of only 3.1 and $0.7 \mu \mathrm{g} / \mathrm{cm}^{2}$ were obtained. This then suggests that for $0.01 \mathrm{M} \mathrm{MnCl}_{2}$ only $10 \%$ of the charge passed contributed to oxidation of $\mathrm{Mn}$ (II) to manganese dioxide, while in the case of $0.001 \mathrm{M} \mathrm{MnCl}_{2}$, only $2.6 \%$ of the charge passed contributed to electrodeposition. This behavior is also seen in the diffusion-limited cases, where, given that we see masses calculaled from inlegrating the current passed during deposition equalling 20.6 and $22.1 \mu \mathrm{g} / \mathrm{cm}^{2}$ for 0.01 and $0.001 \mathrm{M} \mathrm{MnCl}$, respectively, we would expect, based on the trend show $\pi$ in other chloride-based depositions, masses cqual to 26.2 and $28.1 \mu \mathrm{g} / \mathrm{cm}^{2}$. As with the non-diffusion limited cases, we sec masses much lower than this expected result. with the EQCM masses cqualling 3.2 and $0.4 \mu \mathrm{g} / \mathrm{cm}^{2}$, suggesting that for these deposition conditions, only 16 and $2 \%$ of the charge passed during chronoam. perometry is actually involved in the deposition of the $\mathrm{MnO}_{2}$ product.

This behavior in the chloride-based electrolytes is attributable to enhanced stabilization of the soluble Mn(III) intermediate, most likely through complexation of the manganese ions with chloride anions in solution. The fact that we only see this type of behavior in high acid concentration solutions, which is dependent on the disproportionation of Mn(III) (refer to Section 1.3) can give clues as to the factors that contribute to this hehavior. As this is dependent on the interaction between $\mathrm{Mn}^{31}$ ions in solution, it would stand to reason that the frequency of this dispropontionation would te lower in solutions that contain lower concentrations of $\mathrm{Mn}(\mathrm{II})$; i.c. 0.01 and $0.001 \mathrm{M} \mathrm{MnCl}_{2}$. As these solutions are also high in acid $(0.1 \mathrm{M} \mathrm{HCl})$, the chloride is far in excess of the Mn(III), in ratios of approximately 10:1 and 100:1. Therefore, a combination of the relatively long lifespan of
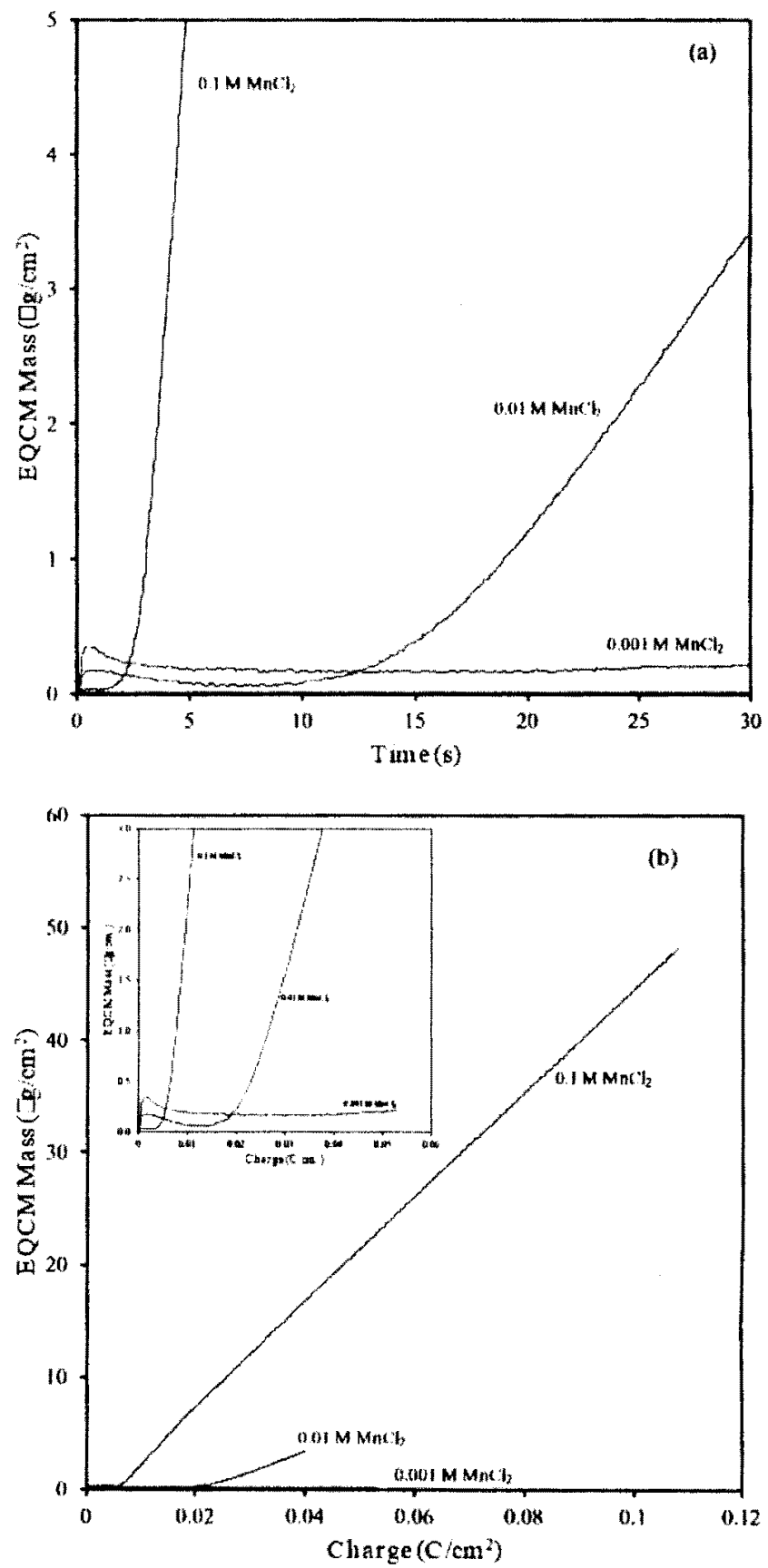

Figure 4. Comparison between the (a) mass versus time and (b) mass versus charge chronoamperomeltic deposition dala for $0.1,0.01$ and $0.001 \mathrm{M} \mathrm{MnCl}_{2}$ in $0.1 \mathrm{M} \mathrm{HCl}$. The step potential was $1.250 \mathrm{~V}$ versus SCE.

the $\mathrm{Mn}(\mathrm{III})$ intermediale in high acid and high chloride conditions would most likely lead to the formution of a complex species such as $\left|\mathrm{Mn}\left(\mathrm{OH}_{2}\right)_{6-2} \mathrm{Cl}_{\mathrm{x}}\right|^{2 \times 27}$

The electrodeposition mass (oblained via EOCM) versus time data for this chloride system can possibly give some insight into the deposition mechanism. If we directly compane deposition data for $0.1,0.01$ and $0.001 \mathrm{M} \mathrm{MnCl}_{2}$ in $0.1 \mathrm{M} \mathrm{HCl}$ in the mass transport-limited case, as shown in Figures $4 a$ and $4 \mathrm{~h}$, the differences are readily highlighted. In Figure 4 a we have plotted deposit mass versus deposition time, whilc in Figure 4 th we have plotted deposit mass veruus charge passed. For $0.1 \mathrm{M} \mathrm{MnCl}_{2}$ in Figure 4a, there appears to be an induction time of $\sim 1 \mathrm{~s}$, where the $\mathrm{Mn}^{21}$ has begun approaching the electrode surface, 


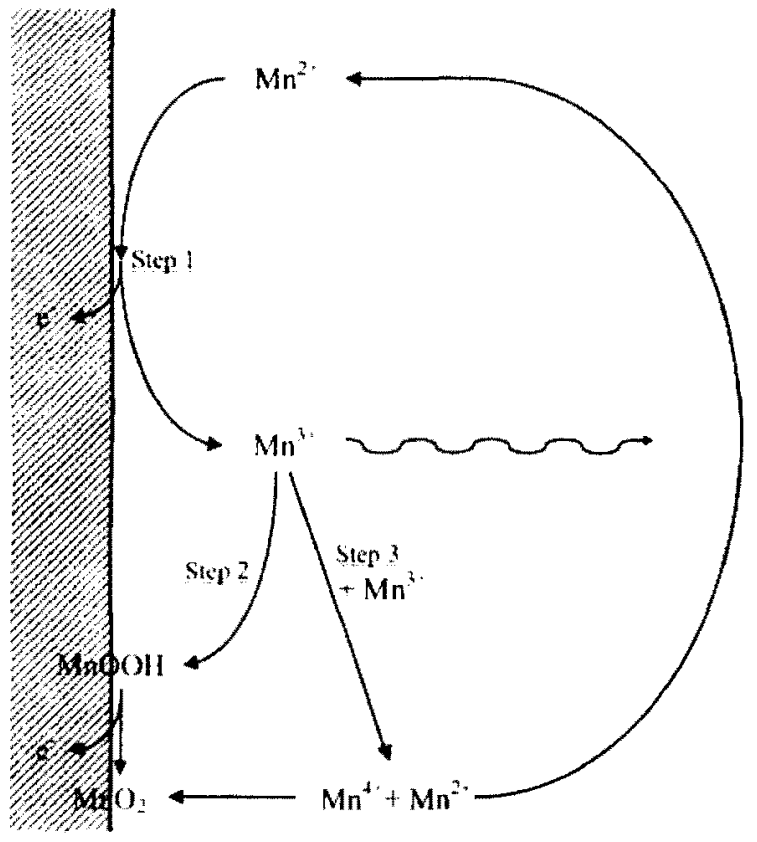

Flpure 5. Revised electrodeposition mechanism.

but has not gained a critical amount to be hydrolysed or disproportionate, and thus be deposited, but after this period electrodeposition begins, and the mass increases in a steady fashion approximalely proportional to that expected from the current. The $0.01 \mathrm{M}$ and $0.001 \mathrm{M}$ $\mathrm{MnCl}_{2}$ solutions, however, present a less straight forward case. Both show a maximum in clectrode muss at short times, corresponding to the same amount of charge passed, as seen in Figure $4 b$, followed by an increase in mass, which is more pronounced in the $0.01 \mathrm{M}$ $\mathrm{MnCl}_{2}$ casc. The implication with a constant amount of charge passed to achieve the same process is that the process must involve some critical concentration level. This process can possibly be explained in terms of the deposition mechanism previously outlined in this work. with this new process summarized in Figure 5 .

After the potential step is applied to the electrode and the surface becomes polarized, the $\mathrm{Mn}^{2+}$ will begin to diffuse to the electrode surface where it is oxidized to $\mathrm{Mn}^{3+}$ (Step 1). After this, the $\mathrm{Mn}^{3+}$ can either diffuse out into the bulk solution, or undergo hydrolysis, leading to the deposition of $\mathrm{MnOOH}$ (Step 2), which is able to undergo a final solid-state oxidation to $\mathrm{MnO}_{2}$. The $\mathrm{Mn}^{3+}$ intermediate is also capahle of disproportionating with another $\mathrm{Mn}^{3+}$ ion, giving $\mathrm{Mn}^{2+}$ and $\mathrm{Mn}^{4}$ (Step 3), the latter of which then undergoes hydrolysis to form manganese dioxide. From the deposition mass versus time data shown in Figure 4, it appears that the $0.1 \mathrm{M} \mathrm{MnCl}_{2}$ solution undergoes electrodeposition of $\mathrm{MnO}_{2}$ via Steps 1,2 and 3. For the $0.01 \mathrm{MMnCl}_{2}$, it would appear that we see an initial fast deposition, most likely of the first deposition product, $\mathrm{MnOOH}$. After this, it would appear that for a short period of time, there is a close competition between two processes, the first of which is dissolution of $\mathrm{MnOOH}$, as evidenced by the slight decrease in mass, and after a period where the ions have reached a saturation point, the further deposition of both $\mathrm{MnOOH}$ and $\mathrm{MnO}_{2}$ in some proportion, which ufter a sufficient period of time dominales over the dissolution. This would also appear to be the case for $0.001 \mathrm{M} \mathrm{MnCl}{ }_{2}$; however, as the increase in mass is not as significant; i.e., from $0.16 \mu \mathrm{g} / \mathrm{cm}^{2}$ at the minimum, to $0.22 \mu \mathrm{g} / \mathrm{cm}^{2}$ at $30 \mathrm{~s}$, as opposed to the $0.01 \mathrm{M}$ electrolyte where the minimum is $\sim 0.06 \mu \mathrm{g} / \mathrm{cm}^{2}$, and increases to $3.4 \mu \mathrm{g} / \mathrm{cm}^{2}$ at the completion of deposition. This would suggest that the $0.001 \mathrm{M} \mathrm{MnCl}_{2}$ solution is close to the equilibrium concentration of the deposition/dissolution of the $\mathrm{MnOOH}$.
This behavior was also observed for the diffusion-limited cases, where the difference between higher $\left(0.1 \mathrm{M} \mathrm{MnCl}_{2}\right)$ and lower $(0.01$ and $0.001 \mathrm{M} \mathrm{MnCl}_{2}$ ) concentrations is considerable. As before, the $0.1 \mathrm{M} \mathrm{MnCl}_{2}$ shows a brief $(\sim 1 \mathrm{~s})$ induction time, after which the deposition continues in a steady manner, and achieves a mass of $\sim 52 \mu \mathrm{g} / \mathrm{cm}^{2}$ after $30 \mathrm{~s} .0 .01$ and $0.001 \mathrm{M} \mathrm{MnCl}$, also show electrodeposition behavior similar to the mass uransport-limited case observed before, in that after initial increases in mass, corresponding to saturation of the electrode surface by $\mathrm{Mn}^{2+}$, a decrease in mass, indicative of competition between dissolution of $\mathrm{MnOOH}$ and deposition of $\mathrm{MnOOH} / \mathrm{MnO}_{2}$, is observed $0.01 \mathrm{M} \mathrm{MnCl} 2$ shows an increase in mass after the minimum mass has been achicved, suggesting that the conditions during deposition are more favorable toward the deposition, rather than dissolution, of mass on the electrode, whereas the $0.001 \mathrm{M}$ solution, shown to have a relatively constant mass after the initial increase, is more towand the equilibrium between dissolution and deposition of product. Mass versus time for these non-diffusion limited cases are shown in Figure 4. II should also be noted that the phenomena of induction times for electrodeposition were observed only in chloride-based solutions, further suggesting that, of the studied anions, the Mn(III) intermediate is only stabilized by chloride anions in solution.

RRDE anatysis.-.. To further support the new deposition mechanism, RRDE was used to determine the percentage of Mn(III) lost to the solution during electrodeposition. An example of the typical disk and ring currents are shown in Figure 6, and the compiled collection efficiency data for all anions, concentration of acid and concentration of $\mathrm{Mn}(\mathrm{II})$ salt are shown in Table I.

It is shown that the percentage of $\mathrm{Mn}(\mathrm{III})$ is typically below $10 \%$, and in the cases of 0.01 and $0.001 \mathrm{M} \mathrm{H}_{2} \mathrm{SO}_{4} . \mathrm{HCl}$ and $\mathrm{HNO}_{3}$, generally $<1 \%$, excluding $0.01 \mathrm{M} \mathrm{HCl}+0.1 \mathrm{M} \mathrm{MnCl}_{2}$ case. An interesting feature in the $\mathrm{SO}_{4}{ }^{2-}, \mathrm{Cl}^{-}$and $\mathrm{NO}_{3}{ }^{-}$series is the consistent trend of the $0.1 \mathrm{M}$ acid solutions showing collected $\mathrm{Mn}$ (III) percentages that are at least one onder of magnitude larger than the lower acid concentrations, most likely due to the high-acid dependence of the $\mathrm{Mn}^{3+}$ disproportionation reaction during deposition, as well as the relatively long lifetime of the Mn(III) intermediate..$^{16-20}$

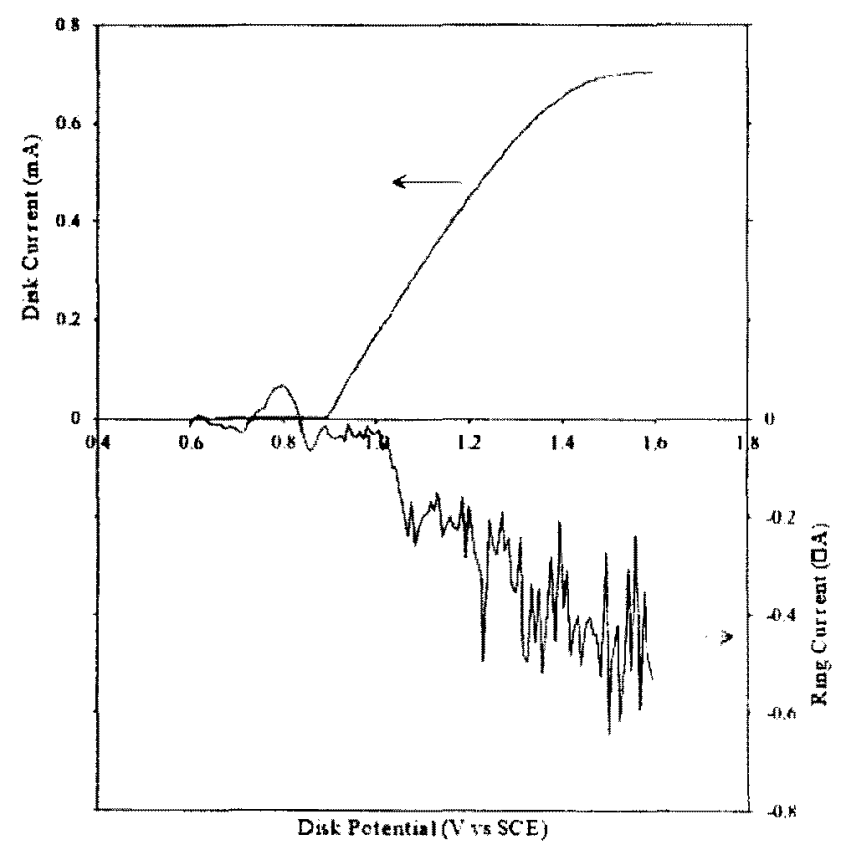

Figure 6. Typical RRDE data for $0.01 \mathrm{M} \mathrm{MnSO}_{4}+0.001 \mathrm{M} \mathrm{H}_{2} \mathrm{SO}_{4}$, with both disk and ring currents shown. 
The most interesting feature of this data is the $0.1 \mathrm{M}$ IICI series, which showed Mn(III) percentages ranging from 29-92\%, which is at least a three-fold increase when compared to the highest Mn(III) content found in the sulfate series, and similarly, a four-fold increase when compared the nitrate solution that exhibited the highest amount of $\mathrm{Mn}$ (III). The $0.1 \mathrm{M} \mathrm{HCl}+0.001 \mathrm{M} \mathrm{MnCl}_{2}$ depositions in particular, with a recovered $\mathrm{Mn}$ (III) content of $92 \%$, may also explain the large discrepancy between masses calculated by EQCM and charge integration, and lends credence to the earlier inference regarding the enhunced stability of the Mn(III) intermediate during the deposition process.

Superapacinor electrode performance.- Cycling for all deposits is typical for previously observed conditions, with typical voltameiric dala for sulfale, thloride, nitrate and acetule daka shown in Figure $7 \mathrm{a}$, with the corresponding cycling performance shown in Figure $7 \mathrm{~b}$. As with previous studies, ${ }^{17}$ the thest-performing electmos tend to be those electrodeposited from a solution containing a high concentration of acid (0.1 M), a low concentration of $\mathrm{Mn}^{2+}(0.01-0.001 \mathrm{M})$, and from non-diffusion or mass transport limited deposition potentials (varies depending on the solution, but generally 0.9-1.25 V versus SCE). The specific capacitance will of eourse vary depending on whether or not the normalizing factor; i.e., mass, is calculated via the current passed during deposition, or the mass measured from the EQCM data - this difference is obviously the difference between the mass from integration and EQCM (cf. 14\% for chloride, $27 \%$ for sulfate, $34 \%$ for acetule, and $40 \%$ for nitrate) and is especially noticeable in the $0.1 \mathrm{M}$ HCl series, where specific capacilances vary between $35 \mathrm{~F} / \mathrm{g}$ for charge-derived mass, as opposed to $4670 \mathrm{~F} / \mathrm{g}$ for EQCM calculaled mass. Compiled specific capacitance datu for all anions, acid concentrations, $\mathrm{Mn}^{2+}$ concentrations and deposition polentials are shown in Table 1 . It is important to note that, as has been described in our previous work, ${ }^{13}$ some of the specifie capacitances obtained from this study were above the theoretical specific capacitance for manganese dioxide $(1386 \mathrm{~F} / \mathrm{g})$. As described in our previous work, ${ }^{13}$ we believe this is due to a combination of both pseudo-capacitive behavior and double layer charging.

Discussion - The combination of integrating chronoamperometic current, EQCM and RRDF, presents an interesting picture. Comparison of masses derived from integration of current during electrodeposition and EQCM show that the EOCM-calculated masses are generally greater than masses derived from the amount of charge passed during deposition. This increase ranges from $14-40 \%$ depending on the anion. The order of observed increase in mass by EQCM is chloride $(14 \%)$, sulfute $(27 \%)$, acetate $(34 \%)$ and nitrate $(40 \%)$. This trend of greater mass from EOCM when compared to current integration would suggest that the factors that would increase mass, such as the inclusion of water or the deposition anion into the electrodeposited structure, have a more appreciable cffect on the mass of the electrode filnı. This is also correlated with the perentage of Mn(III) detected by RRDE. which shows that for the most part, the factor that would contribute the greatest toward the loss of clectrode film mass at these deposition potentials; i.c., the loss of soluble Mn(III) species to the electrolyte, as opposed to $\mathrm{O}_{2}$ evolution, is less than $10 \%$. The most noteworthy exception to this are the solutions containing $0.1 \mathrm{M} \mathrm{HCl}$, and in particular, the lower concentrations of the $\mathrm{Mn}$ (II) salt; i.e., 0.01 and $0.001 \mathrm{M}$. As previously observed, the percentage of $\mathrm{Mn}$ (III) detected by RRDE was found to be in the range $29-92 \%$, with the mass calculated from EOCM accounting for only $10 \%$ and $2.6 \%$ of the mass that would be expected from integrating the charge passed during deposition. The reasons for this can explained in terms of the complexation of $\mathrm{Mn}(\mathrm{III})$ with the various anions.

Previous examples in the Jiterature have shown that while certain anionic ligands such as sulfate can stabilize the Mn(III) state in solution, they undergo slow decomposition. Manganic (Mn(III) acetate has also been previously deseribed to as an oxo-centered $\left[\mathrm{Mn}{ }^{\prime \prime \prime} \mathrm{O}\left(\mu-\mathrm{O}_{2} \mathrm{CMc}\right)_{6}\right]^{\prime}$, and often referred to as $\mathrm{Mn}(\mathrm{OAc})_{3}, 2 \mathrm{H}_{2} \mathrm{O}$ or $\mathrm{Mn}_{3} \mathrm{O}(\mathrm{OAc})_{1} \mathrm{HOAc}^{23}$ Nitrate-based ligands have also been
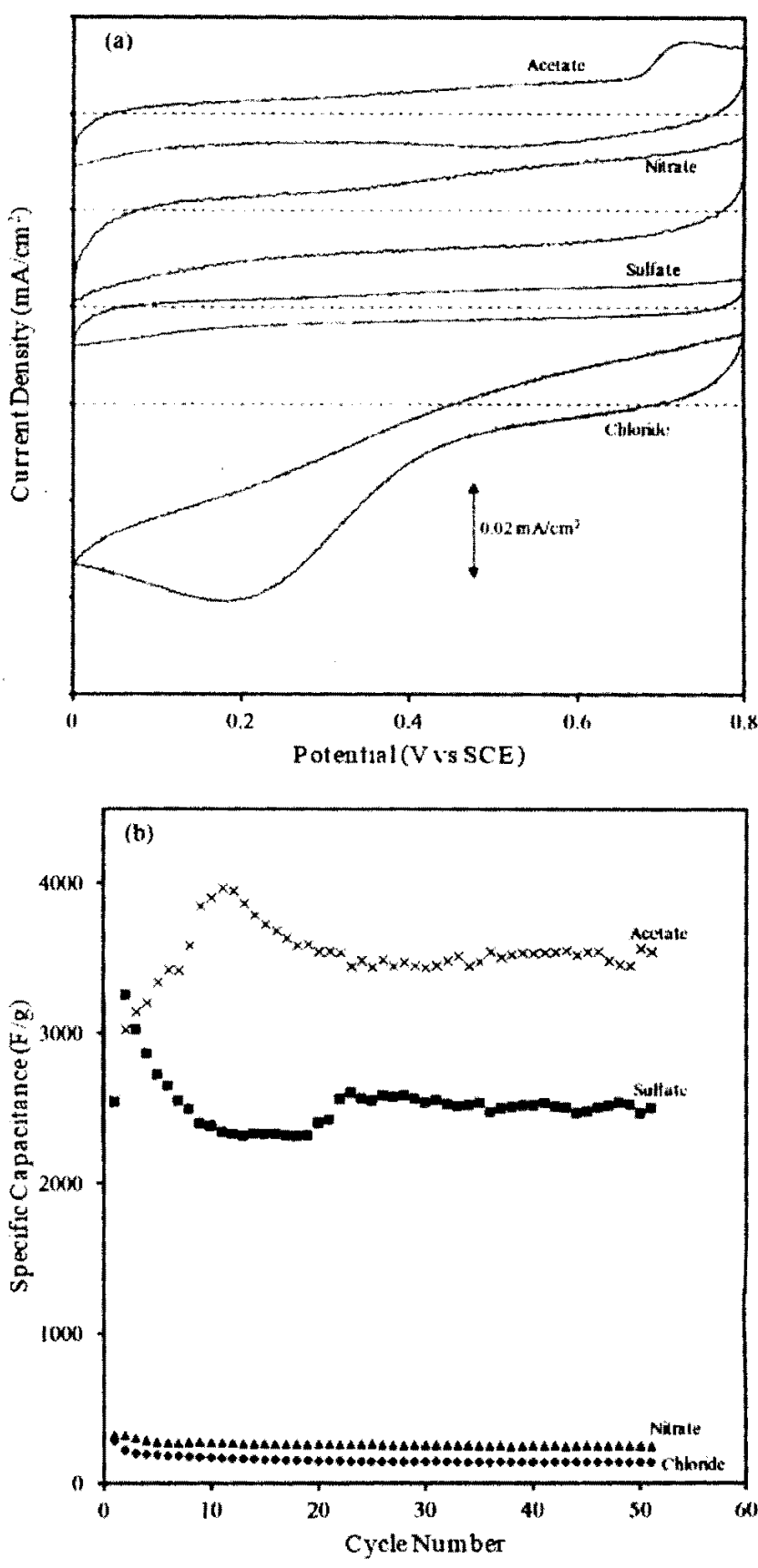

Figure 7. Cycling performance data on the manganese dioxide electrodes prepared using the various anion containing solutions. (a) Sample cyclic voltarnmetry dala (0.1 $\mathrm{M}$ acid $+0.01 \mathrm{M} \mathrm{Mn}^{2+}$ electrolyle; $50^{\text {th }}$ cycle) and (b) specific capacitance as a function of cycle number for the comsponding samples.

described; $;^{24}$ however, it is reasonable to assume that oxygen would be the electron pair donor rather than the nitrogen, and thus it is expected that in would behave more like an oxygen ligand such as sulfale, acetate, oxalate, etc., rather than a ligand that donales an electron pair from the nitrogen, such as an amine, amide or azide. Halides, particularly chloride ligands, have been reported in many complexes with $\mathrm{Mn}(\mathrm{III})$, such as the $\left[\mathrm{MnCl}_{5}\right)^{2}{ }_{25,26}$ anion in the form of $\left(\mathrm{Ft}_{4} \mathrm{~N}_{2} \mathrm{MnCl}_{5},{ }^{27}\right.$ hipyridine $\left(\left(\mathrm{MnCl}_{3}(\right.\right.$ hipy $\left.) l_{n}\right),{ }^{28.29}$ and complexes with imides such as $\mathrm{MnCl}\left(\mathrm{NBu}^{1}\right)_{3},{ }^{30}$ and also the ion $\left[\mathrm{MnCl}_{6}\right]^{3},{ }^{26}$ in addition to the myriad of methods of synthesizing $\mathrm{MnCl}_{3}, 3$ " 3 "

The combination of the relatively longer lifetime of the Mn(III) intermediate in the second step of the high-acid deposition 
mechanism; i.e., dispmoportionation of $\mathrm{Mn}^{34}$ ion as opposed to hydrolysis, the relative concentrations of the Mn(III), and the chloride in solution, and selectivity for chloride complexes with $\mathrm{Mn}$ (III) would explain the lower than expected EQCM masses for solutions containing high concentrations of $\mathrm{HCl}(0.1 \mathrm{M})$ and low concentrations of $\mathrm{MnCl}_{2}(0.01$ and $0.001 \mathrm{M})$. From mass versus time data, it can also be inferred that for these lower concentrations of $\mathrm{MnCl}_{2}$, there uppeauss to be an induction time associated with reaching a critical amount of $\mathrm{Mn}^{2+}$ in solution to begin electrodeposition, and after which, a competition bel ween the dissolution of the deposited $\mathrm{MnOOH}$ and deposition of $\mathrm{MnOOH}$ and/or $\mathrm{MnO}_{2}$ lakes place. $0.001 \mathrm{M} \mathrm{MnCl}_{2}+0.1 \mathrm{M} \mathrm{HCl}$ in particular, due to the slightly increasing mass versus time after the induction time, is particularly representative of the equilibrium between this dissolution/deposition, with these conditions slightly favoring the deposition. In these conditions, however, the vast majority of charge that is passed during chronoamperometry is presumably going to the oxidation of $\mathrm{Mn}^{2+}$ to $\mathrm{Mn}^{31}$, which then undergoes complexation with chloride in solution, rather than deposition of $\mathrm{MnOOH}$ and subsequent oxidation to $\mathrm{MnO}_{2}$.

\section{Conclusions}

This work has detailed the similarities and differences in thin-films of manganese dioxide electrodeposited from four salts of $\mathrm{Mn}(\mathrm{II})$ and their corresponding acids. Comparisons were made between the electrode mass calculated via integration of current during chronoamperometric elcetrodeposition or using EQCM, calculation of the proportion of solublc Mn(III) by RRDF, as well as performance cvaluations using cyclic voltammetry. Notable findings include:

(i) The EQCM mass ranged from 14-40\% higher than that calculated from current integration. This difference was dependent on the anion. This suggests that any mass difference was due to the inclusion of water or forcign cations and anions from the deposition solution rather than any other competing processes that would lower the mass, suth as $\mathrm{O}_{2}$ evelution or soluble $\mathrm{Mn}(\mathrm{III})$ loss.

(ii) The most noleworthy exception was deposition of manganese dioxide from solutions of $0.1 \mathrm{M} \mathrm{HCl}$, particularly with 0.01 and $0.001 \mathrm{M} \mathrm{MmCl}_{2}$. Ifere the EQCM mass was only $2.610 \%$ of the mass expocted from current integration. This is due to the stability of Mn(III) in high-acid electrolytes, and the presence of excess complex forming chloride ions in the electmlyte. Evidence of competition between $\mathrm{MnOOH}$ dissolution, and deposition of $\mathrm{MnOOH}$ and $\mathrm{MnO}_{2}$ is also shown for these solutions.

(iii) RRDE experiments support the previous point, where the percentuge of soluble Mn(III) lies between 29-92\%, whereas for all other solutions it was less than $10 \%$, and often less than $1 \%$.

(iv) Better electrochemical performance as a supercupacitor electrode was achieved with (a) activation limited deposition potentials, (b) higher concentrations of acid, and (c) lower concentrations of $\mathrm{Mn}(\mathrm{II})$.

\section{Acknowledgments}

AC wishes to acknowledge funding provided by the CSIRO Division of Energy Techmology, as well as the University of Newcastle to undertake this research.

\section{References}

I. R. M. MeKentie, Mineral Mag., 38, 493 (197)

2. R. G. Burns und V. M. Hurns, Pros. Manganese Dioxide Symp., 1975

3. V. M. Hums, K. G. Bums, and W. K. Zwikker, Prot. Manyunese Diuxide Symp. 1975.

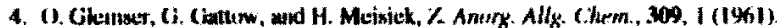

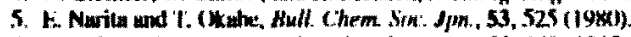

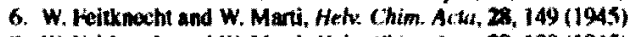

7. W. Feilknecht and W. Marti, Het. Chim. Ak $\mathrm{k}, 28,129$ (1945)

8. H. M. IChn, K. A. Kousm, and K. H. Nealson, NATO ASI Ser. Ser. C. 351, 1/3 (1991).

9. H. Y. Lee and J. A. Goodenough, J. Sold State Chem, 144. 220 (1999)

10. J. P. Zheng. P. J. Cygan, and T. R. Jow, J. Wlecinchem. Six., [42, 2699 (1995).

11. H. Y. Lee, S. W. Xim, and H. Y. Lee, Electinchen, Solid State Lett, 4, A 19 (200)1).

12. T. Shinomiya V. Gupta, and N. Miura, Electnchim. Acta, 51,4412 (2006).

13. A. Cross, A. Morel, A. Cormie, T. llollenkamp, and S. Donne, J. Awer Sources, 1\%, $7847(2011)$.

14. A. D. Cruss, A. Morel, T. I: llollenkump, and S. W. Donne, J. Llecinkhem. Six: 158, A1160 (2011)

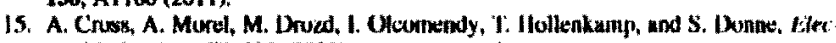
inxhimicu Ack $\mathbf{2} 8,133(2013)$

16. C. J. Clurke, G. J. Browning, and S. W. Donne, Lirctrochim. Atta, 51, 5773 (2106)

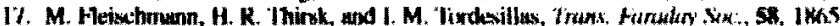
(1962).

18. W. H. Koo and V. J. Weibel, J. Aypl titetan hem., 22, 21 (1992).

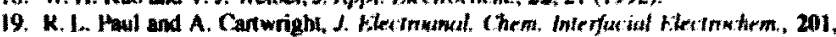
$123(1986)$.

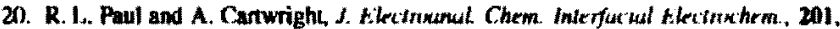
113 (1986).

21. G. Sauertrey, Zeiuschriff far Physik, 155, 206 (1959)

22. A. Cross, A. Cormie, A. F. Hollenkamp, and S. W. Donne, Performance of mangancese dioxide-based clectric double-layer capaciturs, in: 1SEE'Cay09. Nanles, France 2009.

23. K. D. Donnelly, W. E. liristud. H. J. Gellerman. J. R. Peteroun. and B. J. Selle, fetro hedren Lell. 25, 607 (19:4).

24. Y. A. Simonuv, A. A. Dvorkin, V. I. Shul' gin, O. V. Konnik, and V. Y. Chirva, Kimunt. Khin. 17, 1344 (14)1).

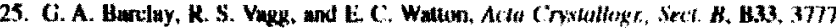
(1977).

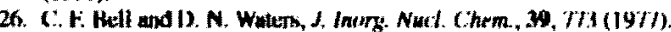

21. C, Belliten, A. A. G. Jomlinsom, and C. Furtani, J. Chem. Sok: A, 326il (19/1).

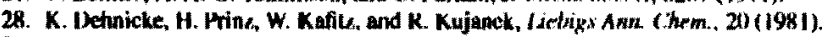

29. H. A. Goodwin and K. N. Sylva, Akst. J. Chem, 20,629 (196i).

30. A. A. Danopoulos, G. Wilkinson. T. K. N. Sweet, and M. A. Hursthouse, J. Chent. Six:, Bullun Irass. 937 (1995)

31. G. Aromi, M. J. Knapp, J.-P. Claude, J. C. Huffman, D. N. Hendrickson, and G. Christow, J. An. Chem. S(x., 121, 5489 (1990)

32. P. V. Nha, N. T. Cung, P. K. Duy, and M. T. Nguyen, Chem. Phys, 400, 185 (2012)

33. C. Paun, V. Purvulescu, O. Seicanu, 1. Dumitru, and G. Simion, Manganese ammonium phosphate-based cosmetic pigment manulacture by oxidation of manyanese sulfute or chloride, in, Inatitutul de Cencelare, Inginerie Tehnologica, Proieclare si Protuctie or chloride, in, lastitutul de Cencelare, Inginerie Tehnologica, Proiectare
pentru Industria Anorganica si Metale Neferuase, Kom.. 1991, pp. 3.

34. K. Prodhus, G. L. Gutser, C. A. Wettherlurd, and P. Jena, J. Chem, Phys, 134, $234311234311(2011)$.

35. M. Barber, J. W. Limadt, und N. II. Taylor, J, (hem, Six, 3323 (19,1).

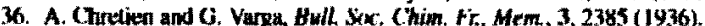

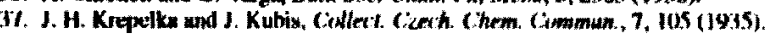

